\title{
18. STRENGTH AND DEFORMATION BEHAVIOR OF SEDIMENT FROM THE LESSER ANTILLES FOREARC ACCRETIONARY PRISM ${ }^{1}$
}

\author{
Kate Moran ${ }^{2}$ and Harold A. Christian ${ }^{2}$
}

\begin{abstract}
The shape and morphology of the northern Barbados Ridge complex is largely controlled by the sediment yield and failure behavior in response to high lateral loads imposed by convergence. Loads in excess of sediment yield strength result in nonrecoverable deformations within the wedge, and failure strength acts as an upper limit beyond which stresses are released through thrust faults. Relatively high loading rates lead to delayed consolidation and in-situ pore pressures greater than hydrostatic. The sediment yield and failure behavior is described for any stress path by a generalized constitutive model. A yield locus delineates the onset of plastic (non-recoverable) deformation, as defined from the isotropic and anisotropic consolidation responses of high-quality 38-mm triaxial specimens; a failure envelope was obtained by shearing the same specimens in both triaxial compression and extension. The yield locus is shown to be rotated into extension space and is centered about a $K$-line greater than unity, suggesting that the in-situ major principal stress has rotated into the horizontal plane, and that the sediment wedge is being subjected to extensional effective stress paths.
\end{abstract}

\section{INTRODUCTION}

ODP Leg 110 drilling focused on the deformation front within the northern Barbados Ridge complex (Fig. 1) to study its geological evolution (Mascle, Moore et al., 1988). As part of this study, whole-round subsamples were collected from selected advanced piston core (APC) intervals in the drill holes for determination of sediment strength and deformation behavior. This behavior controls the generation of in-situ pore pressure, formation of faults within the wedge including the décollement, and ultimately the shape of the accretionary prism.

Brandon (1984) proposed the application of constitutive models developed from soil mechanics to predict the deformational behavior of saturated sediment during subduction and accretion. This unique approach can be used to explain the variety of deformational styles associated with modern accretionary prisms. The experimental data presented here can be used in the application of a constitutive model as proposed by Brandon (1984).

Six boreholes were drilled along a west-east transect across the lower arc. Eleven triaxial shear-strength tests were completed from three of these boreholes. The testing program was designed so that a failure criterion and yield behavior could be defined for the sediment within the wedge. Samples were consolidated under isotropic and anisotropic conditions and were deformed to failure under conditions of triaxial compression and extension. The failure envelope and stress-normalized yield surface are presented as well as estimates of the in-situ stress conditions that are interpreted from sediment laboratory behavior.

\section{CONCEPTS}

In this study, sediment strength ( $\mathrm{T}$ ) is characterized using the Mohr-Coulomb failure criterion (e.g., Terzaghi, 1943), which bounds a region in stress space within which failure does not occur. The failure envelope is given by:

$$
\tau=c^{\prime}+\sigma^{\prime} \tan \phi^{\prime}
$$

\footnotetext{
${ }^{1}$ Moore, J. C., Mascle, A., et al., 1990. Proc. ODP, Sci. Results, 110: College Station, TX (Ocean Drilling Program).

2 Atlantic Geoscience Centre, Bedford Institute of Oceanography, Dartmouth, Nova Scotia, Canada.
}

where $\tau$ and $\sigma^{\prime}$ are the shear and effective normal stresses at failure, $c^{\prime}$ is the effective cohesion, and $\phi^{\prime}$ is the effective angle of shearing resistance. Effective stress is defined as the total stress minus the pore-water pressure and acts on the sediment skeletal frame. One example of sediment failure is the formation of faults. If the stresses applied to a sediment package remain within the failure envelope (Fig. 2), then no failure occurs.

In addition to this failure criterion, a separate yield criterion is defined. Yielding occurs when sediment moves from predominantly elastic to predominantly plastic deformation. The concept of an ideal yield surface is based on plasticity theory (Hill, 1950) where, if the stress state falls within the surface, no plastic deformation occurs. If the stresses applied to the material satisfy the yield function, then nonrecoverable deformations occur (plastic strain). This definition of yield criterion can be used to describe strain-hardening (Fig. 2) so that within the accretionary wedge the sediment can also be characterized to dewater and gain strength under increasing stress. In a geologic setting where the sediment is only subjected to gravitational loads, consolidation or dewatering will occur where rates of sedimentation permit effective stresses to increase. Normally, the sediment will consolidate under different lateral and vertical stresses at a constant stress ratio $(K)$, along a $K$-line represented by line AB (Fig. 2 ). As sediment consolidates and drains along this $\mathrm{K}$-line, the yield or consolidation surface expands in stress space, and the sediment is said to strain-harden. $K$ is defined as the ratio of insitu effective horizontal stress to in-situ effective vertical stress and is termed the coefficient of lateral stress (Lambe and Whitman, 1969). A special case of $K$, termed the coefficient of lateral stress at rest or $K_{\mathrm{o}}$, defines the condition where no in-situ lateral strain occurs. The tectonic setting studied here is characterized by large lateral strains and the conditions are therefore non- $K_{\mathrm{o}}$.

\section{METHODS}

The triaxial test apparatus used to carry out this research program was originally developed at Imperial College by Bishop and Wesley (1975) and has since been modified and upgraded (Menzies, 1987) so that stress path tests are now handled under computer control. The test apparatus can perform many types of advanced tests such as anisotropic consolidation at any stress ratio, $K_{\mathrm{o}}$ consolidation and swelling, drained or undrained shear in compression or extension, as well as conventional isotropically consolidated tests. The general configuration of the triaxial test system is illustrated in Figure $3 \mathrm{~A}$; a diagram of the Bishop Wesley hydraulic triaxial cell is shown in Figure 3B. 

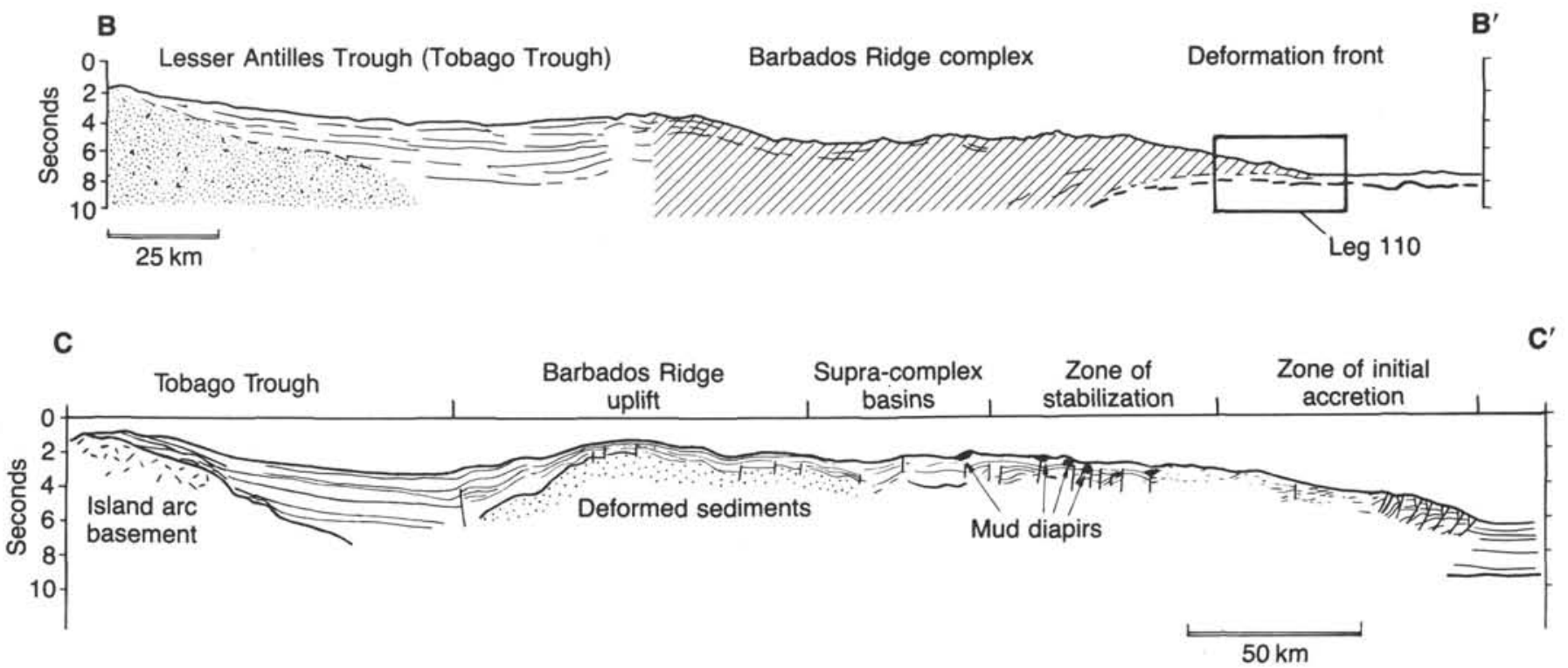

Figure 1. Line drawings of seismic sections across the Lesser Antilles forearc (from Mascle, Moore, et al., 1988).
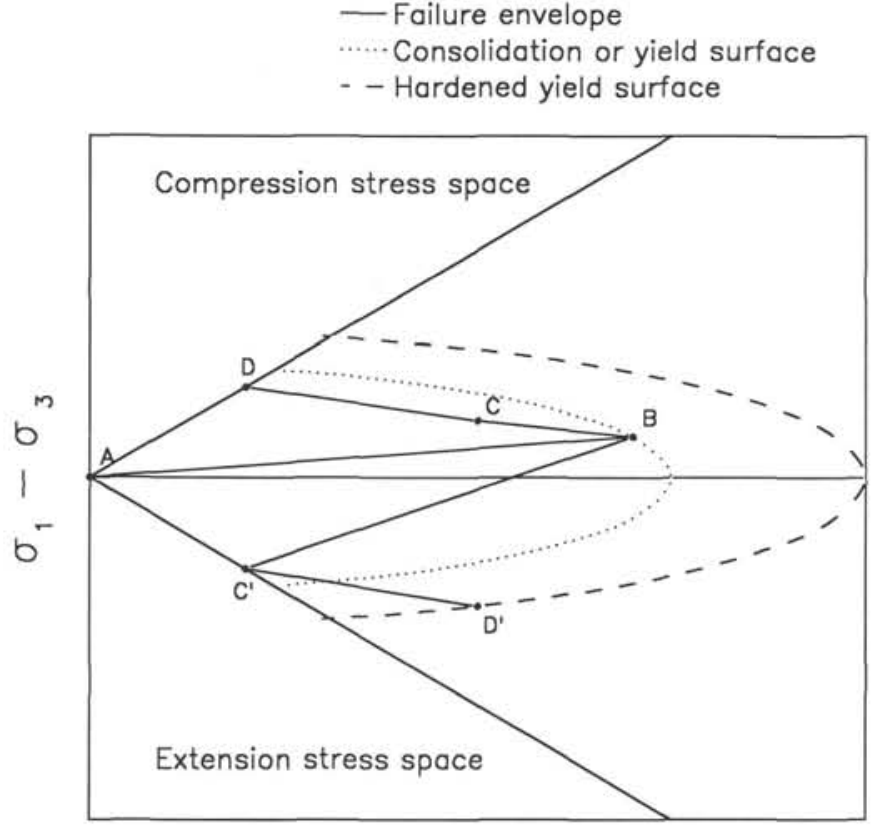

$$
\left(\sigma_{1}+2 \sigma_{3}\right) / 3
$$

Figure 2. Definition of the Mohr-Coulomb failure envelope and the consolidation (yield) surface. Line AB represents sediment consolidation; note that the yield surface expands as sediment consolidates. Line BC represents a stress path where the sediment is rapidly loaded and pore pressure increases. Stress increases due to additional vertical loading moves the sediment to failure along $\mathrm{CD}$. Sediment may also move along stress path $\mathrm{BC}^{\prime}$ into extensional stress space when high lateral loads from convergence cause rotation of principal stresses. Stress path $\mathrm{C}^{\prime} \mathrm{D}^{\prime}$ represents sediment dewatering in extension with associated movement of the yield envelope to a hardened yield envelope.

The triaxial cell is connected to three microcomputer-controlled digital pressure controllers (Menzies, 1987), which are linked to a Hewlett Packard 9000 Series Model 310 computer. The digital controllers are accurate pressure sources and can also function as constant-rate flow pumps for specialized test control. The digital controllers independently regulate back pressure, confining pressure (total radial stress), and load pressure on the triaxial ram (total axial stress).

The sediment sample is encased in a thin latex membrane and is mounted on the cell pedestal that is ported to back pressure, thereby sealing the pore fluid from the confining pressure fluid in the cell. Axial force is applied to the sample by application of pressure to the base of the ram inside a sealed lower chamber in the triaxial cell (Fig. 3B). The piston has a known mass and cross-sectional area, therefore the total axial stress applied to the sample can be calculated (Bishop and Wesley, 1975). Because the computer continuously calculates the axial total stress, no load cell is used with the system. Vertical strains are determined from the volume change in the hydraulic system that controls the pressure on the ram.

Isotropic consolidation $(C I)$ is performed by applying a back pressure to the sample and increasing the cell pressure in increments. Anisotropic consolidation $(C A)$ is performed by incrementally loading the sample radially and axially at a selected ratio of principal stress. $K_{\mathrm{o}}$ consolidation $\left(C K_{\mathrm{o}}\right)$ is a special case of anisotropic consolidation where no lateral strain is allowed. For this case, the initial sample diameter is maintained by computer control by assuming that the sample maintains the shape of a right circular cylinder. Once the triaxial sample has been reconsolidated past its estimated in-situ vertical stress, it was sheared to failure in axial compression (C) or extension (E), in a drained (D) or undrained (U) condition. Pore-pressure was measured by the pore-pressure controller during undrained shear tests. For drained tests a constant back pressure was maintained and volume change was measured. Axial compression is easily performed by loading the sample axially with the ram (Fig. 3b). Axial extension tests are possible using a special extension head developed at Imperial College (Menzies, 1987) that is attached to the top of the sample and prevents confining pressure from acting axially on the sample. This configuration allows the axial stress to be reduced below the confining stress. In this study, samples were tested in undrained compression after isotropic consolidation (CIUC), in undrained compression after anisotropic consolidation (CAUC), and $K_{\mathrm{o}}$ consolidation $\left(\mathrm{CK}_{\mathrm{o}} \mathrm{UC}\right)$, in undrained extension after anisotropic consolidation (CAUE), and in drained $K_{\mathrm{o}}$ compression $\left(C K_{\mathrm{o}}\right)$.

Subsamples were sealed in the plastic liner and then in wax and stored at $5^{\circ} \mathrm{C}$ in salt water until testing. Specimens for triaxial testing were trimmed to a diameter of $38 \mathrm{~mm}$ and a height of $76 \mathrm{~mm}$ on a soil lathe with a wire saw directly upon extrusion from the plastic liner. The specimen was mounted on the top of the ram between two porous stones (Fig. 3B). Two latex membranes were placed around the sample with a thin layer of silicon grease between them. Generally, top drainage was used. Full saturation was achieved by raising the confining pressure in stages and observing the pore-pressure, no drainage allowed. The sam- 

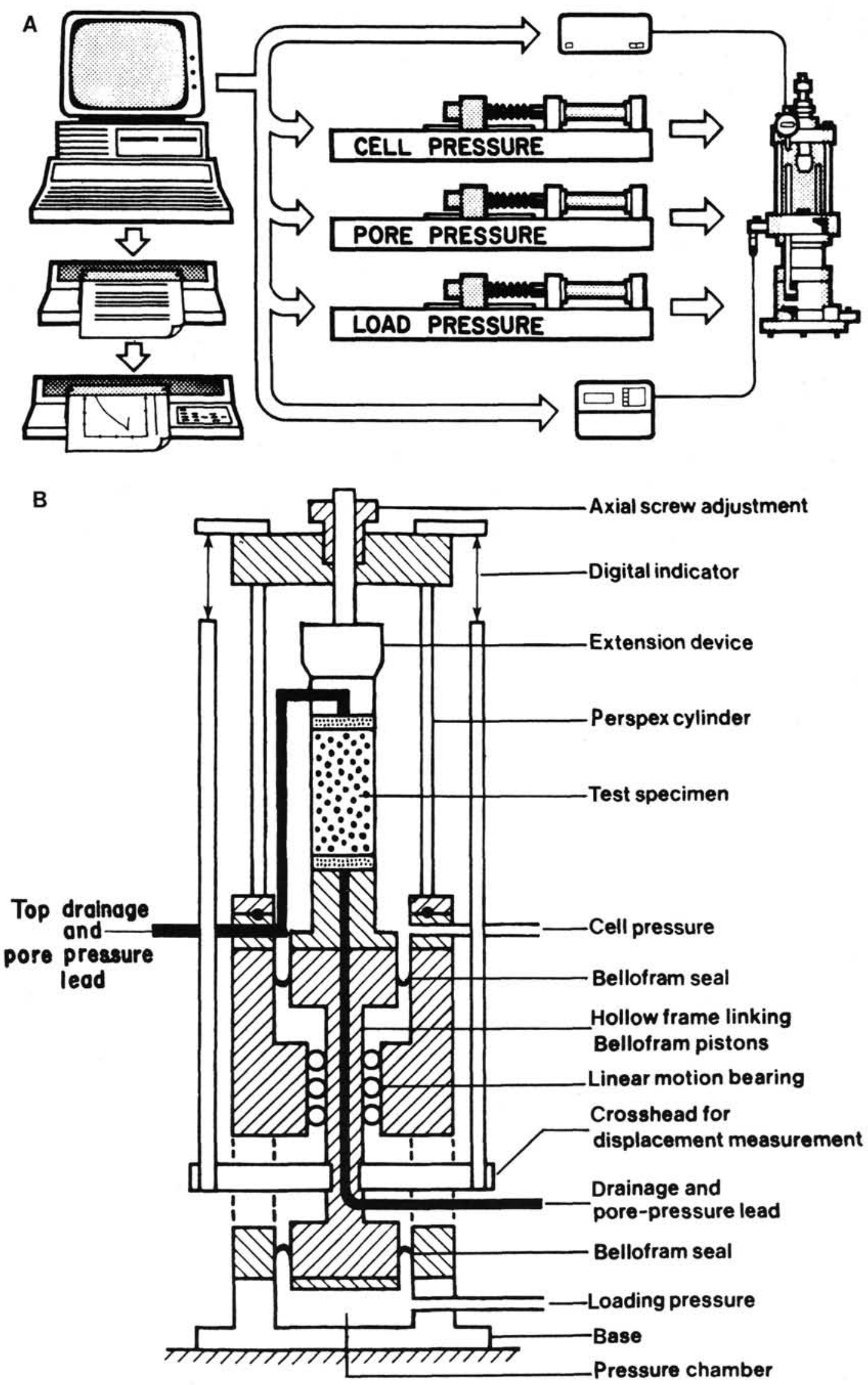

Figure 3. A. General configuration of GDS triaxial test system (after Menzies, 1987). B. Diagram of the Bishop Wesley hydraulic triaxial apparatus for 38-mm specimens (modified from Menzies, 1987). 
ple was then consolidated and sheared to failure. Total stress was applied at a rate of $0.2 \mathrm{kPa}$ per minute in the controlled stress tests and at an axial deformation rate of $0.5 \mathrm{~mm} / \mathrm{hr}$ in the controlled strain tests. These rates were slow enough so that excess pore pressure in response to applied stress was uniform throughout the sample.

Following completion of the test, the sample was removed from the cell, photographed, and described. Final moisture content was then determined. The trimmings from the sample preparation were saved for Atterberg Limit and specific gravity determinations. The salinity was measured and used to correct all water content and void ratio data for dissolved salt content after Noorany (1984).

\section{RESULTS}

\section{Shipboard}

Leg 110 physical properties measured onboard JOIDES Resolution have been presented in Mascle, Moore, et al. (1988) and Wilkens, et al. (this volume). In this study, samples from three of Leg 110 boreholes (671B, 672A, and 676A) were tested. Sites 671 and 676 were located at the deformation front, and 672 was selected as a reference site located $6 \mathrm{~km}$ east of the front (Fig. 4). All samples were of good quality from APC piston cores and within the upper $100 \mathrm{~m}$ of each hole.

The physical properties from onboard measurements generally show the sediment to have increasing undrained vane shear strength and bulk density with depth (Fig. 5). Peak undrained shear strength not only increases with depth (consolidation), but is dependent upon $\mathrm{CaCO}_{3}$ content and grain size. This pattern is exemplified in Fig. 5, where peak shear strength varies, whereas the remolded shear strength increases monotonically with depth.

Physical properties from onboard measurements correlate well. The miniature-vane shear strength range for all samples is between 20 and $150 \mathrm{kPa}$ with lower strengths occurring at shallow depths, and bulk density varies from 1.6 to $1.8 \mathrm{~g} / \mathrm{cm}^{3}$. The density over the depth range of the triaxial samples is generally higher in Holes 671B and 676A (Fig. 5) than in the reference hole, 672A (Wilkens, et al., this volume). The carbonate content is highly variable at depths coincident with the triaxial samples; however, within the zone where two of the triaxial samples were taken (Sections 110-676A-11H-4 and 672A-11H-4) the carbonate content is consistently high (Fig. 5) at approximately $40 \%$.
Measurements of bulk density, water content, and plastic and liquid limits from the same locations as the triaxial samples are plotted with the onboard measurements. The density and water content show little deviation from the onboard measurements (Fig. 5), suggesting no change between sample collection and onshore testing. The natural water content for all samples is within the plastic range (Table 1), but for Hole 671B the natural water content lies closer to the plastic limit, as is expected for a more consolidated sediment.

\section{Failure Envelope}

The stress-strain relationships for individual tests may be described in a number of ways. To define the location in stress space of failure, a peak failure stress must be determined from an evaluation of the stress-strain behavior. In this study, three stress-strain relationships were analyzed to define failure: stress difference $\left(\sigma_{\mathrm{a}}-\sigma_{\mathrm{r}}\right)$ vs. axial strain; stress ratio $\left(\sigma_{\mathrm{a}}{ }^{\prime} / \sigma_{\mathrm{r}}{ }^{\prime}\right)$ vs. axial strain; and excess pore pressure $\left(\mathrm{u}_{\mathrm{e}}\right)$ vs. axial strain (Fig. 6). The peak of the stress ratio curve was found to best define failure. Bishop and Henkel (1962) have shown that the stress ratio parameter provides a fundamental measure of the failure strength. Curves for the anisotropically consolidated samples (Fig. 6B) are slightly less rounded than those for isotropically consolidated samples (Fig. 6A).

The peak failures, when shown in a Cambridge stress field (Roscoe et al., 1958) define the failure envelope (Fig. 2). The angle of the failure envelope in this stress space $\left(\eta^{\prime}\right)$ is related to the Mohr-Coulomb failure envelope friction angle $\left(\Phi^{\prime}\right)$ by:

$$
\tan \eta^{\prime}=\left(6 \sin \phi^{\prime}\right) /\left(3-\sin \phi^{\prime}\right)
$$

The Mohr-Coulomb failure criterion is a linear approximation of Mohr's failure definition. This approximation for sediment from Leg 110 results in $\phi^{\prime}=24^{\circ}$ and $c^{\prime}=9 \mathrm{kPa}$. One extension test was successfully completed to failure. The failure envelope in extension is assumed to be symmetric about the origin (Fig. 7). One triaxial compression test was performed on a scaly fabric sample (test 2, Hole 671B, Pleistocene age), although three additional attempts on similar samples resulted in the sediment breaking apart during trimming. When compared with other triaxial tests, there was no apparent difference in strength for the scaly fabric (Fig. 6A).

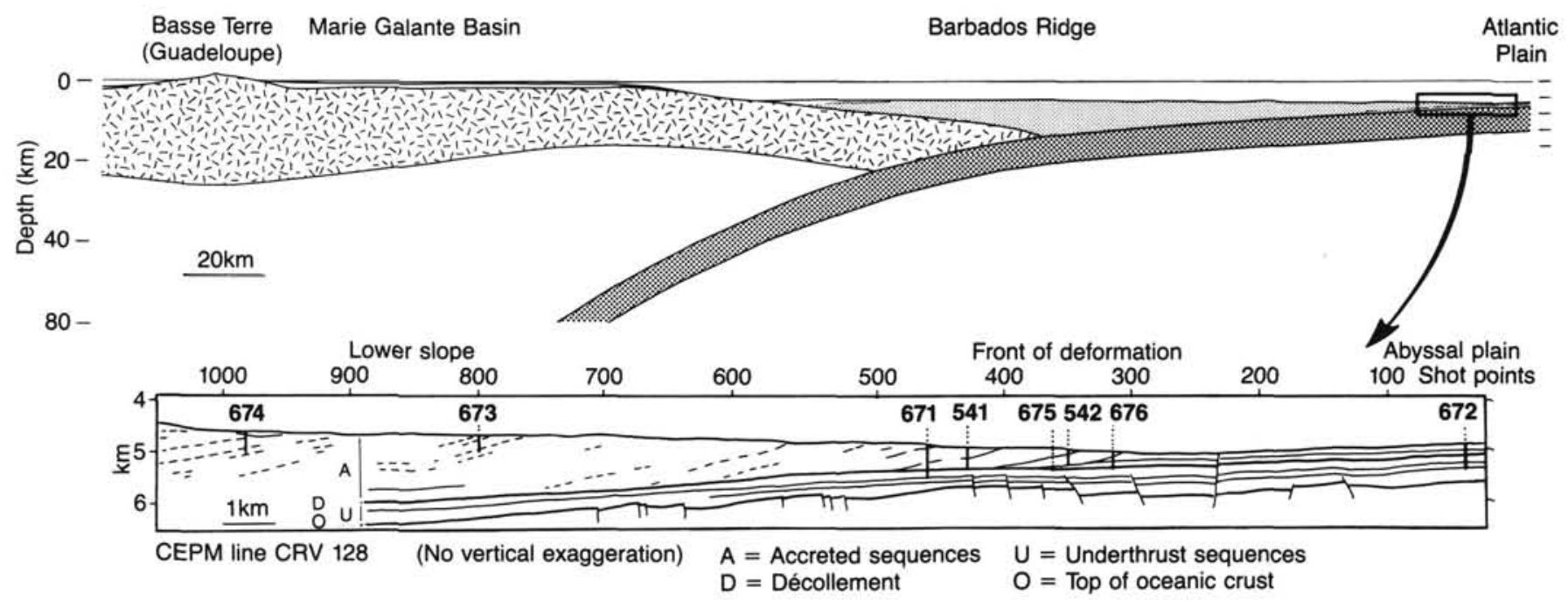

Figure 4. Line drawing from multichannel seismic data (CEPM line CRV 128) showing relative locations of Leg 110 and DSDP Leg 78A sites. In this study, samples from Sites 671, 672, and 676 were tested (from Mascle, Moore, et al., 1988). 


\section{$671 \mathrm{~B}$}



Figure 5. Composites of shipboard physical property data for Holes 671B, 672A, and 676A. The location of each triaxial test is shown on the density profile; the plastic and liquid limit is shown on the water content profile.

\section{Yield}

The locus of effective stress state at which yielding occurs can be represented by the yield envelope (Mitchell, 1970). The shape and size of the yield envelope is defined by the stress history of the sediment as well as its material properties (Crooks and Graham, 1976). Graham et al. (1988) show yield envelopes as symmetrical about a $K_{\mathrm{o}}$-line for a given vertical effective stress. For the study discussed here, where samples were recovered from different depths at a variety of vertical effective stresses each sample has its own in-situ yield surface. To define one yield function from this data set, each yield stress was normalized to its pre-consolidation pressure. Pre-consolidation pressure $\left(P_{\mathrm{c}}{ }^{\prime}\right)$ was determined by Taylor, et al. (this volume) from oedometer tests. However, because oedometer tests were not always located at the same depth as the triaxial tests, data were interpolated and estimated values were selected (Table 2). There is a degree of uncertainty in this method; oedometer tests from the same depth as the triaxial samples would have eliminated this potential source of error.

Yield was defined by averaging the results of several techniques: $s^{\prime}$, stress ratio, and $\log \sigma^{\prime}{ }_{a}$ vs. axial or radial strain. Excellent agreement was found among the three methods, which is consistent with results from Graham et al. (1988). The shape of the normalized yield surface for these accreted sediments is assumed to be elliptical. This assumption of an elliptical yield surface is based on experimental evidence and the Modified CamClay Model (Graham et al., 1988; Roscoe and Burland, 1968). Rotation of the yield surface into extension stress space suggests that this sediment has a high $K$-value $(>1.0)$ and therefore has 


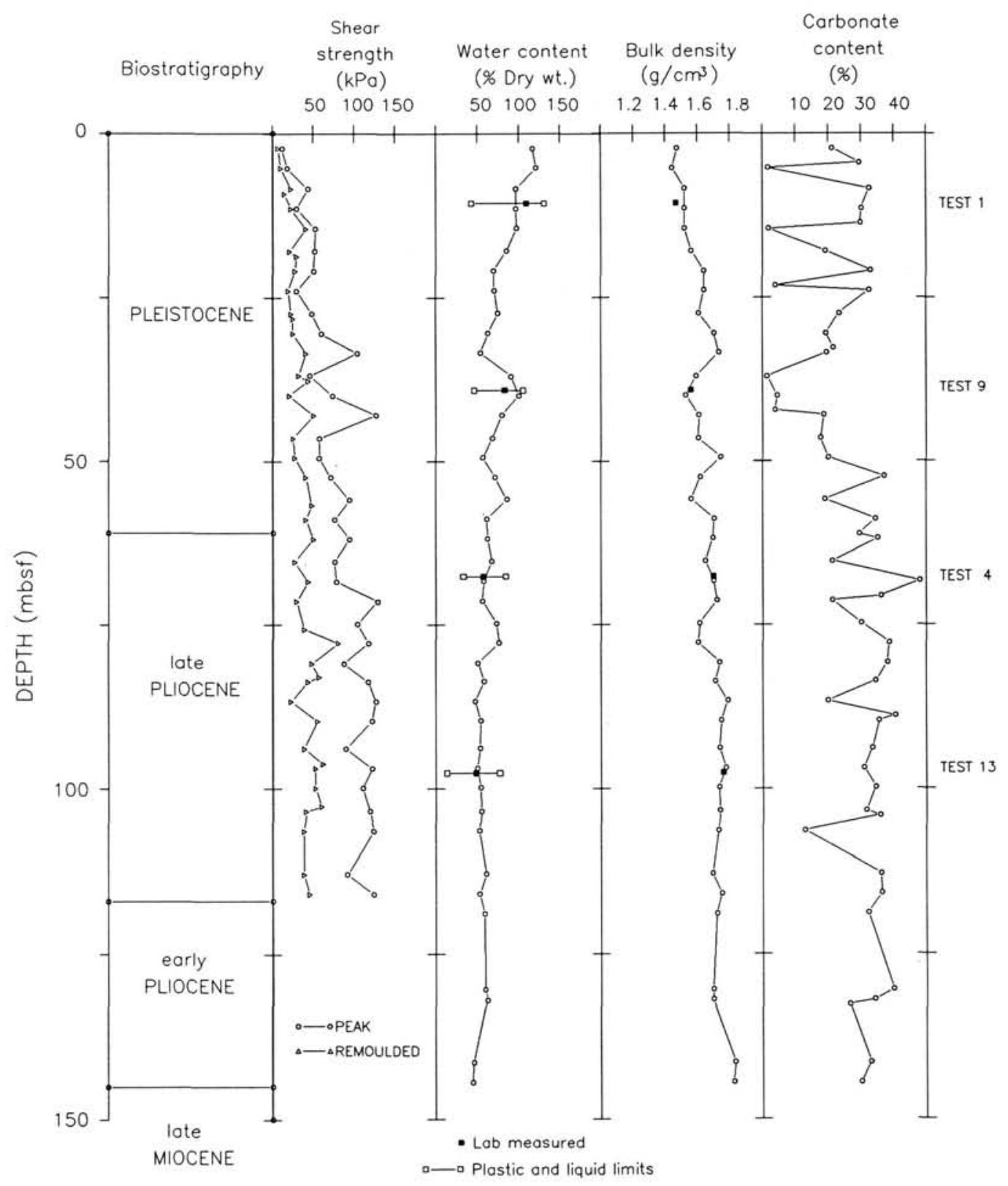

Figure 5 (continued).

experienced rotation of principal stresses. If the center of the yield ellipse is assumed to be the K-axis, then the yield data approximate a $K$ of 1.25 (Fig. 8).

\section{DISCUSSION}

To apply measured strength and deformation properties in prediction or modeling studies, in-situ stress conditions must be known or estimated. This is apparent from both the failure and yield criteria, where failure or yielding is dependant upon the stress state. The vertical effective stress $\left(\sigma^{\prime}{ }_{v} \mathrm{o}\right)$ can be approximated from:

$$
\sigma^{\prime}{ }_{v o}=\delta_{b} z
$$

where $\delta_{\mathrm{b}}$ is the buoyant density of the sediment, and $z$ is the depth below seafloor. This estimate of vertical effective stress assumes that no excess pore pressure exists. Pore pressures are not known for Leg 110 sites. Based on the results of the consolidation tests (Taylor, et al., this volume), the sediment within the accretionary wedge is maintaining pore pressures in excess of hydrostatic. Consequently, because hydrostatic pressure is assumed in equation (3), the vertical effective stress is an upper limit. Although vertical total stress determination is easily estimated, horizontal effective stress $\left(\sigma^{\prime}{ }_{h o}\right)$ cannot readily be determined from laboratory measurements. In soil mechanics, horizontal stress determination is normally represented using the lateral stress ratio, $K$. Only estimates and not actual in-situ values of $K$ can be determined. These estimates, however, can be used as lower bounds (Bjerrum and Andersen, 1972). Data from tests 10 and 11 (Table 2) resulted in high estimates of $K, 0.9$ and 0.7 , respectively. Triaxial test values of $K$ typically vary between 0.5 and 0.6 (Campanella and Vaid, 1972). Consequently, the 


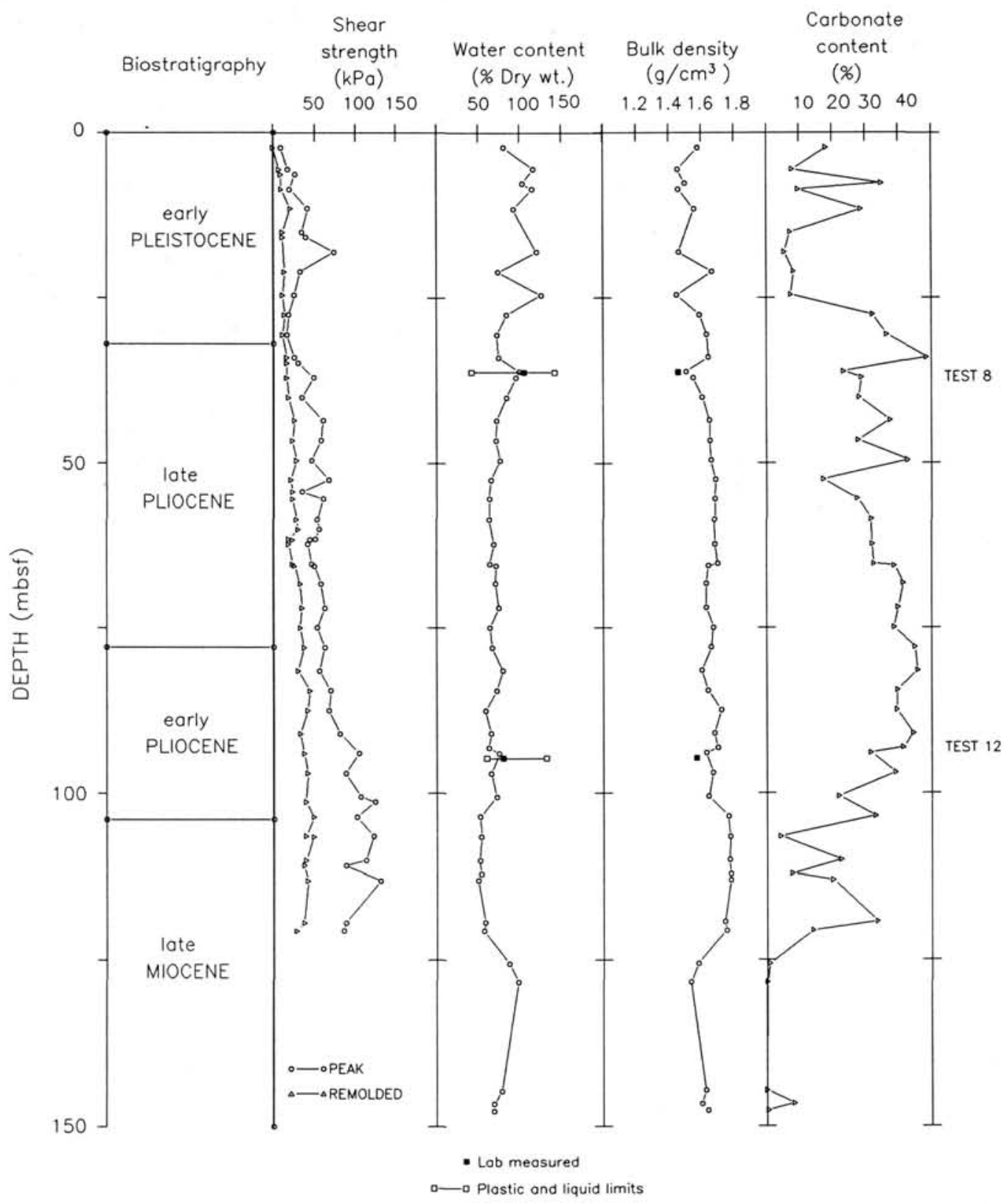

Figure 5 (continued).

high coefficients measured suggest that $\sigma^{\prime}{ }_{h o}$ is higher than $\sigma^{\prime}{ }_{v o}$ $(K>1)$. This suggestion is consistent with a rotation of principal stresses within the accretionary wedge.

The low angle of the failure envelope determined in this study, when coupled with the estimated excess pore pressures interpreted from the consolidation test data (Taylor, et al., this volume) suggests that much of the sediment in the wedge may be close to failure. Consequently, any intermittent additional loading to the wedge may cause localized failure or development of faults in zones of lowest permeability where additional excess pore pressures cannot dissipate.

Fault formation in a convergent margin setting is most likely a progressive failure mechanism (Bjerrum, 1967). The mechanism can be described by studying the potential stress paths of the sediment package as it moves into the zone of convergence. Initially, the sediment is deposited and consolidates in a com- pressional stress regime and follows the stress path of line $\mathrm{AB}$ (Fig. 2). The yield surface moves and expands with this consolidation. As the sediment moves into the convergent zone, two different stress paths can be followed. If the predominant loading condition is caused by additional sediment that is thrust on top of the incoming sediment package, then the stress path followed will remain compressional. Increased pore pressure due to rapid loading will move the stress state away from the yield or consolidation surface in the undrained direction (line BC, Fig. 2). If additional thrusting continues, the incoming sediment may continue in compression following a stress path to the failure envelope (line $C D$, Fig. 2), whereby the incoming sediment begins faulting. Alternatively, the incoming sediment may be experiencing high lateral loads in excess of vertical loads induced by sediment thrust packages. From stress point B (Fig. 2), the sediment would follow a stress path into extension and could poten- 
Table 1. Index property data summary of triaxial samples.

\begin{tabular}{rccrcrrrrrr}
\hline Test & Hole & $\begin{array}{c}\text { Depth } \\
(\mathrm{m})\end{array}$ & $\begin{array}{c}W_{\mathrm{n}} \\
(\%)\end{array}$ & $\begin{array}{c}W_{\mathrm{p}} \\
(\%)\end{array}$ & $\begin{array}{r}W_{1} \\
(\%)\end{array}$ & \multicolumn{1}{c}{$I_{\mathrm{p}}$} & $I_{1}$ & $\begin{array}{c}\text { Bulk } \\
\text { density } \\
\left(\mathrm{g} / \mathrm{cm}^{3}\right)\end{array}$ & $\begin{array}{c}\text { Void } \\
\text { ratio }\end{array}$ & $\begin{array}{c}\text { Specific } \\
\text { gravity }\end{array}$ \\
\hline 1 & $676 \mathrm{~A}$ & 10.64 & 109 & 43 & 131 & 88 & 0.75 & 1.45 & 3.23 & 2.95 \\
2 & $671 \mathrm{~B}$ & 20.95 & 83 & 74 & 155 & 81 & 0.11 & 1.52 & 2.39 & 2.88 \\
4 & $676 \mathrm{~A}$ & 67.65 & 57 & 33 & 84 & 51 & 0.47 & 1.68 & 1.62 & 2.84 \\
8 & $672 \mathrm{~A}$ & 36.24 & 106 & 42 & 142 & 100 & 0.64 & 1.44 & 2.98 & 2.81 \\
9 & $676 \mathrm{~A}$ & 39.12 & 83 & 46 & 126 & 80 & 0.46 & 1.54 & 2.36 & 2.86 \\
10 & $671 \mathrm{~B}$ & 59.36 & 48 & 37 & 78 & 41 & 0.27 & 1.73 & 1.42 & 2.94 \\
11 & $671 \mathrm{~B}$ & 60.83 & 53 & 39 & 88 & 49 & 0.29 & 1.70 & 1.55 & 2.93 \\
12 & $672 \mathrm{~A}$ & 94.74 & 80 & 60 & 132 & 72 & 0.28 & 1.53 & 1.94 & - \\
13 & $676 \mathrm{~A}$ & 97.63 & 48 & 13 & 77 & 64 & 0.55 & 1.74 & 1.21 & - \\
14 & $671 \mathrm{~B}$ & 87.79 & 49 & 49 & 101 & 52 & 0.00 & 1.72 & 1.40 & 2.86 \\
15 & $671 \mathrm{~B}$ & 89.33 & 54 & 35 & 85 & 50 & 0.38 & 1.71 & 1.26 & 2.85 \\
\hline
\end{tabular}

$I_{\mathrm{p}}=$ plasticity index

$I_{1}=$ liquidity index

$W_{\mathrm{n}}=$ water content $(\%$ dry wt. $)$

$W_{1}=$ liquid limit

$W_{\mathrm{p}}=$ plastic limit

tially move to failure (line $\mathrm{BC}^{\prime}$, Fig. 2). After failure (fault formation), local pore-pressure dissipation may occur with associated large deformations represented by movement of the yield surface to a "hardened" yield surface (line C'D', Fig. 2). This deformation causes an increase in pore pressure adjacent to the failed zone and progressive failure propagates until additional faulting occurs.

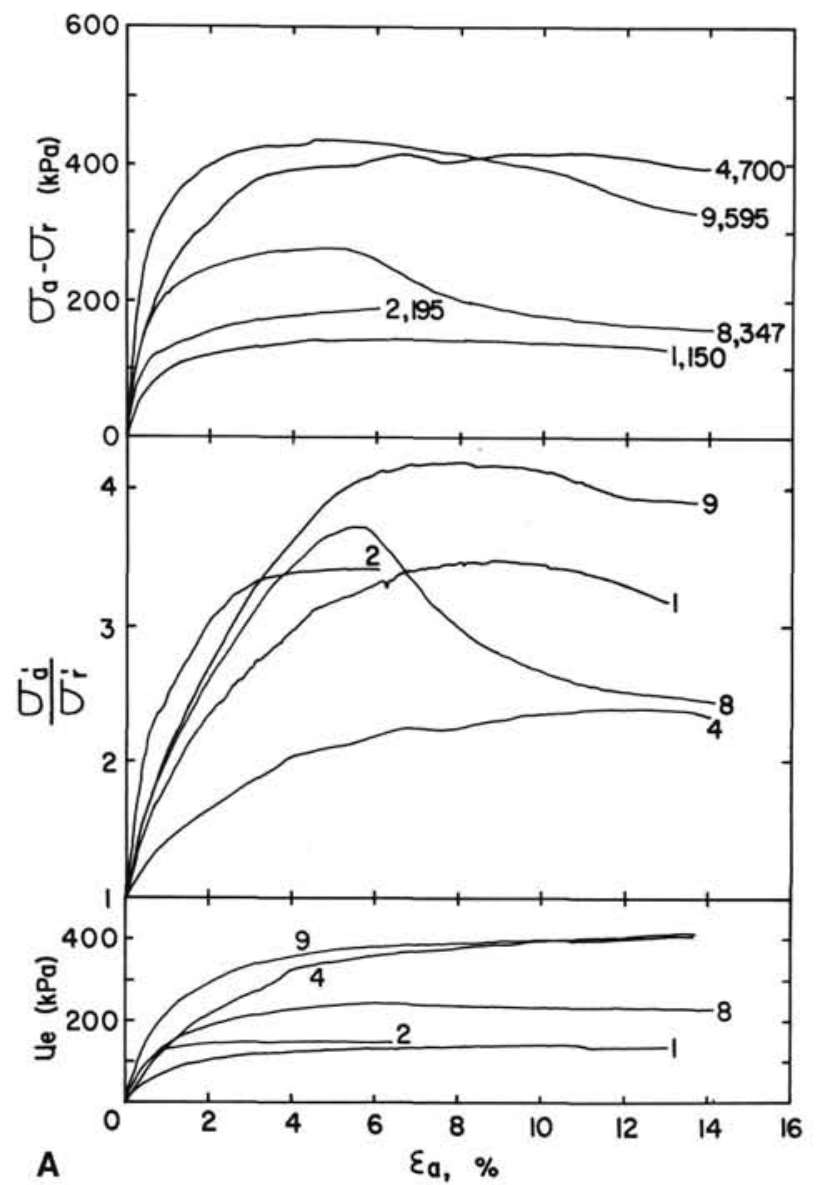

The experimental results from this study suggest that the sediment is deforming within an extensional stress regime (lines $\mathrm{BC}^{\prime} \mathrm{D}^{\prime}$, Fig. 2). However, the evidence is not conclusive due to the limited data set and unknown in-situ stress conditions. In addition, all samples are assumed to be representative of the sediment at the toe of the wedge even though sample lithologies and locations within the sediment wedge vary.

\section{SUMMARY}

Failure criteria and yield behavior have been experimentally determined for sediment from the northern Barbados Ridge complex. Interpretation of the stress-strain and consolidation components of the triaxial data as well as the shape and orientation of the yield function suggest high in-situ lateral stresses. The results of the yield data suggest that the elliptical surface has rotated into extensional space, thus the sediment sampled from all holes has been subjected to a rotation of principal stresses. In addition, the triaxial test estimates of $K$ based on $K_{\mathrm{o}}$ consolidation are high, again suggesting stress rotation.

The failure and yield criteria, when coupled with sediment permeability data (Taylor et al., this volume) can be used as input to continuum models of the formation of the accretionary prism, as suggested by Brandon (1984). In any modeling effort, however, initial stress state conditions must be well defined. Consequently, in-situ stress conditions (i.e., pore pressure and lat-

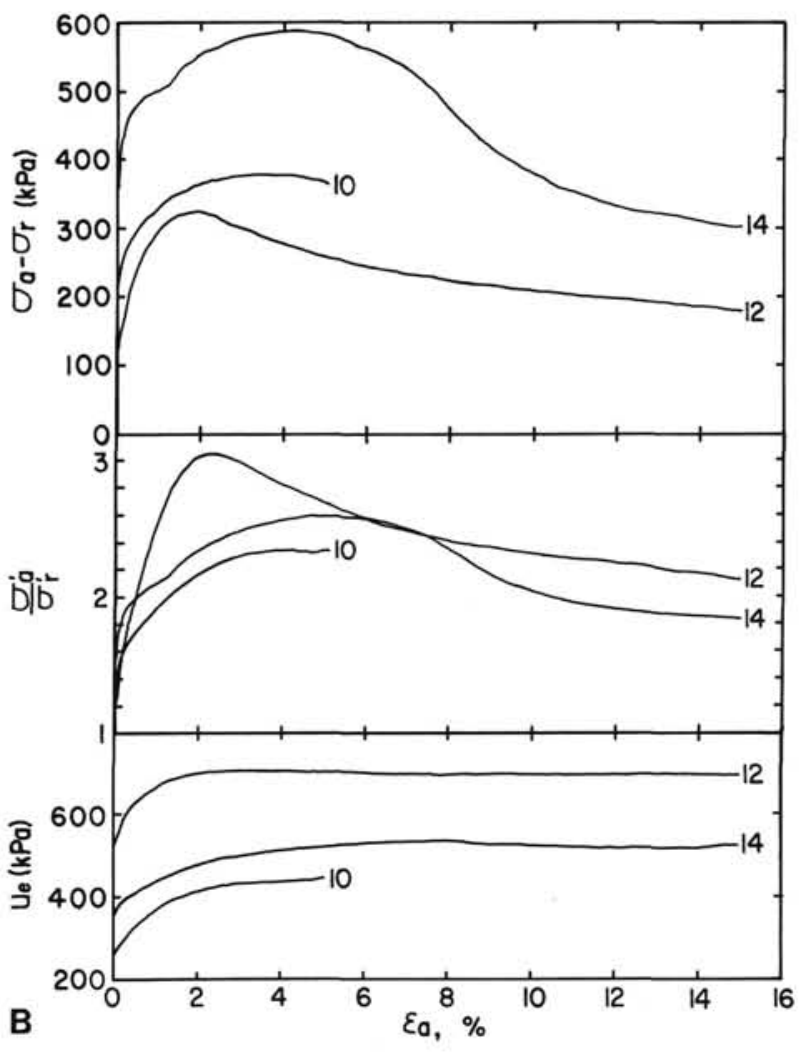

Figure 6. A. Deviator stress vs. strain (upper plot), stress ratio vs. strain (middle plot), and excess pore pressure vs. strain (lower plot) for isotropically consolidated triaxial tests; and B. Deviator stress vs. strain (upper plot), stress ratio vs. strain (middle plot), and excess pore pressure vs. strain (lower plot) for anisotropically and $K_{\mathrm{o}}$ consolidated triaxial tests. The number after each curve is the test number and in Figure 6A (upper plot), the second number is the consolidation stress in $\mathrm{kPa}$. 


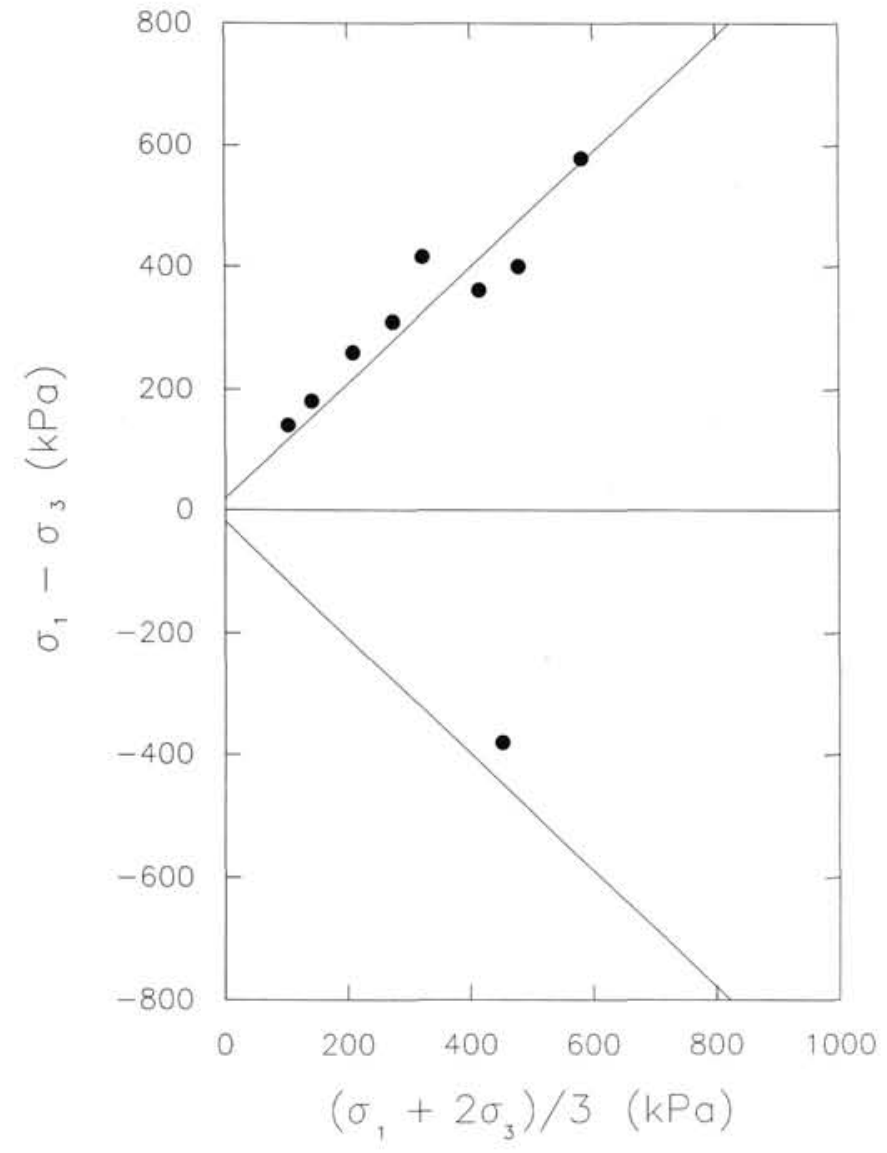

Figure 7. Definition of the failure envelope for accreted sediment from ODP Leg 110. eral stress) should be determined for this geographic study area, as well as for other similar accretionary settings.

\section{REFERENCES}

Bishop, A. W., and Henkel, D. J., 1962. The Measurement of Soil Properties in the Triaxial Test: London (Edward Arnold).

Bishop, A. W., and Wesley, L. D., 1975. A hydraulic triaxial apparatus for controlled stress path testing. Geotechnique, 75:657-670.

Bjerrum, L., 1967. Progressive failure in slopes of overconsolidated plastic clay and clay shales. ASCE J. Soil Mech. Found. Div., 93:3-49.

Bjerrum, L., and Andersen, K. H., 1972. In-situ measurement of lateral pressure in clay. Publication 91: Oslo (Norwegian Geotechnical Institute).

Brandon, M. T., 1984. Deformational Processes affecting unlithified sediments at active margins: a field and a structural model [Ph.D. dissert.]. Univ. of Washington, Seattle.

Campanella, R. G., and Vaid, Y. P., 1972, A simple $\mathrm{K}_{\mathrm{o}}$ triaxial cell. Can. Geotech. J., 9:249-260.

Crooks, J.H.A., and Graham, J., 1976. Geotechnical properties of the Belfast estuarine deposits Geotechnique, 26:293-315.

Graham, J., Cooks, J.H.A., and Lau, S.L.K., 1988. Yield envelopes: identification and geometric properties. Geotechnique, 38:125-134.

Hill, R., 1950. The Mathematical Theory of Plasticity: Oxford (Clarendon Press).

Lambe, T. W., and Whitman, R. V., 1969. Soil Mechanics: New York (Wiley).

Mascle, A., Moore, J. C., et al., 1988. Proc. ODP, Init. Repts., 110: College Station, TX (Ocean Drilling Program).

Menzies, B., 1987. A computer controlled hydraulic triaxial testing system. Proc. ASTM Symp. Adv. Triaxial Testing of Soil and Rock.

Mitchell, R. J., 1970. On the yielding and mechanical strength of Leda clays. Can. Geotech. J., 7:297-312.

Noorany, I., 1984. Phase relations in marine soils. ASCE J. Geotech. Eng., 110:539-543.

Roscoe, K. H., and Burland, J. B., 1968. On the generalised stressstrain behaviour of 'wet' clay. Engineering Plasticity: Cambridge (Cambridge Univ. Press).

Roscoe, K. H., Schofield, A. N., and Wroth, C. P., 1958. On the yielding of soils. Geotechnique, 8:22-28.

Terzaghi, K., 1943. Theoretical Soil Mechanics: New York (Wiley).

Date of initial receipt: 28 November 1988

Date of acceptance: 11 May 1989

Ms 110B-150

Table 2. Triaxial stress conditions and shear strength parameters.

\begin{tabular}{|c|c|c|c|c|c|c|c|c|c|c|c|c|c|}
\hline Test & Hole & $\begin{array}{l}\text { Depth } \\
\text { (mbsf) }\end{array}$ & $\begin{array}{l}\text { Test } \\
\text { type }\end{array}$ & $\begin{array}{l}P_{\mathrm{c}^{\prime}} \\
\mathrm{kPa}\end{array}$ & $\begin{array}{l}\sigma^{\prime} y y \\
\mathrm{kPa}\end{array}$ & $\begin{array}{l}\sigma^{\prime} h y \\
\mathrm{kPa}\end{array}$ & $\begin{array}{l}\sigma^{\prime} v c \\
\mathrm{kPa}\end{array}$ & $\begin{array}{l}\sigma^{\prime} h c \\
\mathrm{kPa}\end{array}$ & $B$ & $A_{\mathrm{f}}$ & $\begin{array}{c}\epsilon_{\mathrm{f}} \\
(\%)\end{array}$ & $\underset{\mathrm{kPa}}{S_{\mathrm{u}}}$ & K \\
\hline 1 & $676 \mathrm{~A}$ & 10.64 & CIUC & 20 & - & - & 195 & 195 & 0.99 & 0.94 & 8.8 & 72 & - \\
\hline 2 & $671 B$ & 20.95 & CIUC & 140 & - & - & 150 & 150 & 0.97 & 0.39 & 6.5 & 94 & - \\
\hline 4 & $676 \mathrm{~A}$ & 67.65 & CIUC & 52 & - & - & 700 & 700 & 0.99 & 0.99 & 13.0 & 205 & - \\
\hline 8 & $672 \mathrm{~A}$ & 36.24 & CIUC & 196 & - & - & 347 & 347 & 0.96 & 0.93 & 6.1 & 134 & - \\
\hline 9 & $676 \mathrm{~A}$ & 39.12 & CIUC & 50 & 43 & 43 & 595 & 595 & 0.80 & 1.09 & 8.1 & 211 & - \\
\hline 10 & $671 \mathrm{~B}$ & 59.36 & $\mathrm{CK}_{\mathrm{o}} \mathrm{UC}$ & 270 & 245 & 230 & 625 & 461 & 0.98 & 0.86 & 3.8 & 187 & 0.9 \\
\hline 11 & $671 B$ & 60.83 & $\mathrm{CK}_{\mathrm{o}}$ & 270 & 240 & 171 & - & - & 1.03 & - & - & - & 0.7 \\
\hline 12 & $672 \mathrm{~A}$ & 94.74 & CAUC & 200 & 172 & 136 & 388 & 351 & 0.97 & 0.82 & 2.3 & 158 & - \\
\hline 13 & $676 \mathrm{~A}$ & 97.63 & CA & 175 & 151 & 123 & - & - & 0.93 & - & - & - & - \\
\hline 14 & $671 \mathrm{~B}$ & 87.79 & $\mathrm{CK}_{\mathrm{o}} \mathrm{UC}$ & 380 & 344 & 174 & 840 & 534 & 0.97 & 0.61 & 5.1 & 290 & - \\
\hline 15 & $671 B$ & 89.33 & CAUUE & 384 & 98 & 155 & 373 & 597 & 0.91 & 0.08 & 0.5 & 195 & - \\
\hline
\end{tabular}

CIUC $=$ isotropic consolidation; triaxial shear in undrained compression

$\mathrm{CAUC}=$ anisotropic consolidation; triaxial shear in undrained compression

$\mathrm{CK}_{\mathrm{o}} \mathrm{UC}=\mathrm{K}_{\mathrm{o}}$ consolidation; triaxial shear in undrained compression

CAUE = anisotropic consolidation; triaxial shear in undrained extension

$S_{\mathrm{u}}=$ undrained shear strength

$\epsilon_{\mathrm{f}}=$ axial or radial strain at failure

$A_{\mathrm{f}}=$ pore-pressure coefficient at failure (Bishop and Henkel, 1962)

$B=$ pore-pressure coefficient (Bishop and Henkel, 1962)

$P_{\mathrm{c}^{\prime}}{ }^{\prime}=$ in-situ vertical pre-consolidation stress

$\sigma^{\prime}{ }_{v y}=$ effective axial yield stress during consolidation

$\sigma^{\prime} h y=$ effective radial yield stress during consolidation

$\sigma^{\prime}{ }^{\prime}{ }_{c c}=$ effective vertical stress before triaxial shear

$\sigma^{\prime}{ }^{\prime} h c=$ effective horizontal stress before triaxial shear

$K \stackrel{h c}{=}$ lateral stress ratio determined from $\mathrm{K}_{\mathrm{o}}$ consolidation 




Figure 8. Definition of the yield envelope for accreted sediment from ODP Leg 110; $t$ and $s^{\prime}$ are normalized to the measured or estimated pre-consolidation pressure $\left(P_{\mathrm{c}}{ }^{\prime}\right)$. 